\title{
Molecular and functional characterization of voltage-gated sodium channels in human sperm
} Francisco M Pinto ${ }^{1}$, Cristina G Ravina² ${ }^{2}$ Manuel Fernández-Sánchez², Manuel Gallardo-Castro ${ }^{1}$, Antonio Cejudo-Román ${ }^{1}$ and Luz Candenas*1

\author{
Address: ${ }^{1}$ Instituto de Investigaciones Químicas, CSIC, Avda. Americo Vespucio 49, 41092 Sevilla, Spain and ${ }^{2}$ IVI-Sevilla, Avenida Republica \\ Argentina 58, 41011 Sevilla, Spain \\ Email: Francisco M Pinto - Francisco.pinto@iiq.csic.es; Cristina G Ravina - crgonzalez@ivi.es; Manuel Fernández-Sánchez - mfernandez@ivi.es; \\ Manuel Gallardo-Castro - md_castro@iiq.csic.es; Antonio Cejudo-Román - antonio.cejudo@iiq.csic.es; \\ Luz Candenas* - luzcandenas@iiq.csic.es \\ * Corresponding author
}

Published: 16 July 2009

Reproductive Biology and Endocrinology 2009, 7:7| doi:|0.|186/1477-7827-7-7|

This article is available from: http://www.rbej.com/content/7/I/7।

(c) 2009 Pinto et al; licensee BioMed Central Ltd.

This is an Open Access article distributed under the terms of the Creative Commons Attribution License (http://creativecommons.org/licenses/by/2.0), which permits unrestricted use, distribution, and reproduction in any medium, provided the original work is properly cited.

\begin{abstract}
Background: We have investigated the expression of voltage-gated sodium channels in human spermatozoa and characterized their role in sperm motility.

Methods: Freshly ejaculated semen was collected from thirty normozoospermic human donors, with each donor supplying 2 different samples. Reverse transcription-polymerase chain reaction (RT-PCR) and immunofluorescence techniques were used to detect the mRNAs and proteins of interest. Sperm motility was measured by a computer-assisted sperm analysis system (CASA). Cytosolic free calcium was determined by fluorimetry in cells loaded with the fluorescent calcium indicator Fura-2.

Results: The mRNAs that encode the different Nav alpha subunits (Navl.I-I.9) were all expressed in capacitated human spermatozoa. The mRNAs of the auxiliary subunits betal, beta 3 and beta 4 were also present. Immunofluorescence studies showed that, with the exception of Navl.I and Navl.3, the Nav channel proteins were present in sperm cells and show specific and different sites of localization. Veratridine, a voltage-gated sodium channel activator, caused time- and concentration-dependent increases in progressive sperm motility. In sperm suspensions loaded with Fura-2, veratridine did not modify intracellular free calcium levels.
\end{abstract}

Conclusion: This research shows the presence of voltage-gated sodium channels in human sperm and supports a role for these channels in the regulation of mature sperm function.

\section{Background}

Voltage-gated sodium channels (VGSCs) play an essential role in the generation of the rapid depolarization during the initial phase of the action potential in excitable cells $[1,2]$. These complex membrane proteins are composed of an $\alpha$ and one or more auxiliary $\beta$ subunits $[2,3]$. The $\alpha$ subunits are large proteins with a high degree of amino acid sequence identity; they contain an ion-conducting aqueous pore and can function without the $\beta$ subunit as a $\mathrm{Na}^{+}$channel [2-4]. Nine different voltage-dependent $\mathrm{Na}^{+}$ channel $\alpha$ subunits have been cloned in mammals, each of which is encoded by a different gene [5]. They can be 
further characterized by their sensitivity to the highly selective blocker tetrodotoxin (TTX). The TTX-sensitive $\alpha$ subunits are inhibited by TTX in the nanomolar range and include SCN1A (also known as $\mathrm{Na}_{\mathrm{v}} 1.1$ ), SCN2A (also known as $\mathrm{Na}_{\mathrm{v}} 1.2$ ), SCN3A (also known as $\mathrm{Na}_{\mathrm{v}} 1.3$ ), SCN4A (also known as $\mathrm{Na}_{\mathrm{v}} 1.4$ ), SCN8A (also known as $\mathrm{Na}_{\mathrm{v}} 1.6$ ), and SCN9A (also known as $\mathrm{Na}_{\mathrm{v}} 1.7$ ). The TTXresistant $\alpha$ subunits are inhibited by TTX in the micromolar range and include SCN5A (also known as $\mathrm{Na}_{\mathrm{v}} 1.5$ ), SCN10A (also known as $\mathrm{Na}_{\mathrm{v}} 1.8$ ), and SCN11A (also known as $\left.\mathrm{Na}_{\mathrm{v}} 1.9\right)$ [2,5]. A tenth, related, nonvoltagedependent atypical $\alpha$ isoform, SCN7A (also known as $\left.\mathrm{Na}_{\mathrm{x}}\right)$, has also been cloned and expressed $[6,7]$. Four different $\beta$ subunits, SCN1B, SCN2B, SCN3B, and SCN4B (also named $\beta_{1-4}$ ) are currently known [8-10]. The roles of the $\beta$ subunits are less well established, although they appear to modulate the cellular localization, functional expression, kinetics, and voltage-dependence of channel gating $[8,10]$.

In mammalian spermatozoa the acquisition of fertilization competence, known as capacitation, occurs during the transit through the female reproductive tract and is accompanied by important changes in sperm motility, intracellular $\mathrm{pH}\left(\mathrm{pH}_{\mathrm{i}}\right)$ and plasma membrane potential $\left(\mathrm{E}_{\mathrm{m}}\right)$ and organization [11-16]. In addition to the pivotal role played by $\mathrm{Ca}^{2+}[17], \mathrm{Na}^{+}$and $\mathrm{K}^{+}$fluxes through plasma membrane may contribute specially to these processes, necessary for the morphological and functional changes of sperm that ultimately lead to interaction with the oocyte $[11,14,18,19]$. Molecular and functional studies of $\mathrm{K}^{+}$channels have revealed that voltage-gated $\mathrm{K}_{\mathrm{v}}$ channels, $\mathrm{Ca}^{2+}$-activated $\mathrm{K}^{+}$channels and inwardly rectifying $\mathrm{K}_{\mathrm{ATP}}$ channels are present and have a potential functional role in sperm $[14,20]$. Regarding $\mathrm{Na}^{+}$channels, Hernández-González et al. [19] reported the involvement of an amiloride-sensitive $\mathrm{Na}^{+}$channel that may contribute to the regulation of resting sperm $\mathrm{E}_{\mathrm{m}}$. The characteristics of these channels match with the family of epithelial $\mathrm{Na}^{+}$ channels $(\mathrm{ENaC})$. Conversely, no studies have been made to characterize the presence of VGSCs in mature spermatozoa.

The major aim of our study was to characterize the presence and function of voltage-dependent $\mathrm{Na}^{+}$channels in capacitated human sperm. For this purpose, we analyzed the expression and localization of VGSC and realized experiments to investigate the effects of the selective VGSC activator veratridine on sperm motility.

\section{Methods}

\section{Semen samples and sperm preparation}

This study was approved by the Ethics Committees of CSIC and Instituto Valenciano de Infertilidad, Sevilla, and all donors gave written informed consent.
Freshly ejaculated semen was collected from 30 donors (18-35 years old) with normal sperm parameters and proven fertility. Samples (2 from each donor) were obtained by masturbation after 3-4 days sexual abstinence and processed immediately upon liquefaction. Quantitative, manual semen analyses were performed on undiluted semen $(5 \mu \mathrm{l})$ with a Makler Counting Chamber (Sefi Medical Instruments, Haifa, Israel). Samples were examined for concentration and motility according to the World Health Organization (WHO, 1999) guidelines. A minimum of 200 cells were counted per $5 \mu \mathrm{ldrop}$, and at least two drops were studied per sample.

Liquefied semen samples were washed with modified human tubal fluid (mHTF) supplemented with 2\% bovine serum albumin (BSA) at $37^{\circ} \mathrm{C}$ and processed for capacitation as previously described [21]. Briefly, sperm suspensions were centrifuged at $400 \mathrm{~g}$ for $20 \mathrm{~min}$ through a discontinuous Percoll density gradient (Spermgrad-125, Vitrolife, Kungsbacka, Sweden). The samples were then centrifuged (400 $\mathrm{g}$ for $15 \mathrm{~min}$ ), and the pellets collected and washed ( $400 \mathrm{~g}$ for $5 \mathrm{~min}$ ) in $2 \mathrm{ml}$ of mHTF. Samples were allowed to swim-up for $1 \mathrm{~h}$ at $37^{\circ} \mathrm{C}$ and the supernatant carefully aspirated. Semen motility and concentration were re-examined and the sperm concentration adjusted to $50 \times 10^{6} \mathrm{cell} / \mathrm{ml}$ for subsequent experiments.

\section{RNA extraction and RT-PCR}

Total RNA from human sperm was extracted using TriReagent (Sigma). The complementary DNA (cDNA) was synthesized using the Quantitect Reverse Transcription kit (Qiagen, Venlo, The Netherlands). Human testis cDNA was obtained from Clontech (Palo Alto, CA, USA). The specific oligonucleotide primers designed to amplify the different voltage-dependent $\mathrm{Na}^{+}$channels $\alpha$ and $\beta$ subunits have been previously used to investigate the expression of VGSC in 20 different human tissues [9] and span at least one exon in each target gene. Primers were also designed to amplify $\beta$-actin (ACTB), which was chosen as a housekeeping gene to control RT-PCR reactions among samples $[21,22]$. Amplification was carried out in $25 \mu \mathrm{l}$ of PCR buffer containing $3 \mu \mathrm{l}$ of cDNA reaction mixture, 2.5 $\mathrm{mM} \mathrm{MgCl}_{2}, 0.2 \mu \mathrm{M}$ primers, $200 \mu \mathrm{M}$ dNTPs and $1.5 \mathrm{U}$ of heat-activated thermostable DNA polymerase (Immolase, Bioline, London, UK). PCR was performed for 35 cycles with cycling parameters of $15 \mathrm{~s}$ at $94^{\circ} \mathrm{C}, 20 \mathrm{~s}$ at $60^{\circ} \mathrm{C}$ and $20 \mathrm{~s}$ at $72^{\circ} \mathrm{C}$. The PCR products were separated by agarose gel electrophoresis and the amplicon sizes were verified by comparison with a DNA mass ladder. The identity of each product was established by DNA sequence analysis. Each assay was performed in triplicate and three negative controls were run for each assay: no template, no reverse transcriptase and no RNA in the reverse transcriptase reaction. 


\section{Immunofluorescence studies}

Sperm cells were washed, resuspended in phosphate-buffered saline (PBS) and smeared onto poly-L-lysine-coated slides. Spermatozoa were then fixed by incubation in cold methanol $\left(-20^{\circ} \mathrm{C}\right)$ for $20 \mathrm{~min}$. Slides were washed three times for 10 min with PBS and incubated with $2 \%$ BSA in PBS for 30 min to block non-specific sites. Test slides were incubated with a primary polyclonal antibody designed to recognize $\mathrm{Na}_{\mathrm{v}} 1.1$ (sc-16031, goat), $\mathrm{Na}_{\mathrm{v}} 1.2$ (sc-28753, rabbit), $\mathrm{Na}_{\mathrm{v}} 1.3$ (sc-22202, goat), $\mathrm{Na}_{\mathrm{v}} 1.4$ (sc-28751, rabbit) and $\mathrm{Na}_{\mathrm{v}} 1.5$ (sc-22758, rabbit), from Santa Cruz Biotechnology (Santa Cruz, CA); $\mathrm{Na}_{\mathrm{v}} 1.6$ (asc-009, rabbit) from Alomone Labs (Jerusalem, Israel); $\mathrm{Na}_{\mathrm{v}} 1.7$ (ab-65167, rabbit), $\mathrm{Na}_{\mathrm{v}} 1.8$ (ab-66743, rabbit), $\mathrm{Na}_{\mathrm{v}} 1.9$ (ab-65160, rabbit) and $\mathrm{Na}_{\mathrm{x}}$ (ab-66499, rabbit), from Abcam (Cambridge, UK). All these primary antibodies were diluted 1:100 in PBS containing 2\% BSA and incubated overnight at $4^{\circ} \mathrm{C}$. The specificity of antibodies was assessed by the supplier or by pre-absorption with the corresponding immunogenic peptide when available. Negative control slides were not exposed to the primary antibody and were incubated with a) rabbit or goat IgG fraction or b) PBS and then processed in the same conditions as the test slides. Samples were washed three times in PBS, and incubated for 60 min with appropriate FITCconjugated secondary antibodies (Santa Cruz). Slides were further washed in PBS, mounted using Vectashield (Vector Laboratories, Burlingame, CA) and examined with a Olympus BX-51 fluorescence microscopy (Tokyo, Japan) using a 100× immersion objective.

\section{Human sperm motility studies}

Motility analysis was conducted by computer-assisted sperm analysis (CASA) (Sperm Class Analyzer, S.C.A., Microptic, Barcelona, Spain). Setting parameters and the definition of measured sperm motion parameters for CASA were established by the manufacturer: number of frames to analyze: 25; number of frames/s: 25; straightness (STR) threshold: $80 \%$; cell size range (low): 2; cell size range (high): 60 ; volume $\geq 3.0 \mathrm{ml}$; sperm concentration $/ \mathrm{ml} \geq 20 \times 10^{6} \mathrm{cell} / \mathrm{ml}$; forward motility $\geq 60 \%$. To measure both sperm concentration and motility, aliquots of semen samples $(7.5 \mu \mathrm{l})$ were placed into a pre-warmed $\left(37^{\circ} \mathrm{C}\right.$ ) Makler counting chamber (Sefi Medical Instruments, Haifa, Israel). A minimum of 100 sperm from at least two different drops of each sample was analyzed from each specimen. The motility pattern of sperm samples was established following WHO guidelines and defined as: "A" grade sperm (rapidly progressive with velocity $25 \mu \mathrm{m} / \mathrm{s}$ ), "B" grade (slow/sluggish progressive with velocity $5 \mu \mathrm{m} / \mathrm{s}$ but $<25 \mu \mathrm{m} / \mathrm{s}$ ), "C" grade (non-progressive motility with velocity $<5 \mu \mathrm{m} / \mathrm{s}$ ) and " $\mathrm{D}$ " grade (immobile) [22-24]. Progressive motility $(A+B)$, nonprogressive motility $(C)$ and immotility $(D)$ were measured as percentage of the total $(A+B+C+D)$ that was con- sidered as $100 \%$. All samples used in this study had values of immotile, grade D spermatozoa lower than $20 \%$ of the total.

To investigate the effects of veratridine, individual sperm samples were divided in several aliquots and each aliquot was treated with a single concentration of veratridine (10${ }^{8} \mathrm{M}, 10^{-7} \mathrm{M}, 3 \times 10^{-7} \mathrm{M}, 10^{-6} \mathrm{M}, 3 \times 10^{-6} \mathrm{M}, 10^{-5} \mathrm{M}$ or $3 \times$ $10^{-5} \mathrm{M}$ ) or the corresponding solvent (time-matched paired controls). Sperm motility was measured $5 \mathrm{~min}$ before agent addition (initial value) and after a contact time of 2, 15, 30 and $60 \mathrm{~min}$. Values of sperm progressive motility, non-progressive motility and immotility were expressed as the positive or negative percentage increment in motility produced by the drug relative to the value observed at the same time in solvent-treated timematched paired controls ( $\Delta$ sperm motility).

\section{Measurements of $\left[\mathrm{Ca}^{2+}\right]_{i}$}

After capacitation and swim-up, spermatozoa were incubated with the acetoxymethyl ester form of Fura-2 (Fura2/AM, $8 \mu \mathrm{M}$, Molecular Probes, Invitrogen, Eugene, OR, USA) for $60 \mathrm{~min}$ at room temperature. After loading, the cells were washed, resuspended in HEPES solution and used within the next 2-4 hours, following previously published procedures [25]. Sperm aliquots (1 ml, $50 \times 10^{6}$ cell $/ \mathrm{ml}$ ) were placed in the quartz cuvette of a spectrofluorometer (SLM Aminco-Bowman, Series 2, Microbeam, Barcelona, Spain) and magnetically stirred at $37^{\circ} \mathrm{C}$. The sperm suspension was alternatively illuminated with two excitations wavelengths (340 $\mathrm{nm}$ and 380 $\mathrm{nm}$ ) and the emitted fluorescence was measured at 510 $\mathrm{nm}$. Changes in $\left[\mathrm{Ca}^{2+}\right]_{\mathrm{i}}$ were monitored using the Fura- 2 (F340/F380) fluorescence ratio as previously described [26,27].

\section{Drugs and solutions}

The modified human tubal fluid was from Irvine Scientific (Santa Ana, CA, USA). The composition of the HEPES solution was (in $\mathrm{mM}$ ): $\mathrm{NaCl} 140 ; \mathrm{KCl} 4.7 ; \mathrm{CaCl}_{2} 2.0$; $\mathrm{MgCl}_{2}$ 0.3; glucose 10 and HEPES 10 (pH 7.4). Veratridine was from Sigma. Veratridine was dissolved in DMSO at a concentration of $10^{-2} \mathrm{M}$, aliquoted and stored at $-20^{\circ} \mathrm{C}$ until use. Further dilutions were made in mHTF or HEPES solution on the day of use.

\section{Statistical analysis}

Values (means \pm SEM) were obtained by pooling individual data. Unless otherwise indicated, $n$ represents the number of experiments in sperm samples from $n$ different donors. Multiple means were compared by one-way analysis of variance (ANOVA) followed by Newman-Keuls multiple comparison test. These procedures were undertaken using GRAPHPAD PRISM (version 5.0) program. A value of $P<0.05$ was considered significant. 


\section{Results mRNA expression of voltage-gated $\mathrm{Na}^{+}$channels in human sperm}

The PCR products expected for the $\mathrm{Na}_{\mathrm{v}} \alpha$ subunits $S C N 1 A$ $\left(\mathrm{Na}_{\mathrm{v}} 1.1,225 \mathrm{bp}\right), \operatorname{SCN} 2 A\left(\mathrm{Na}_{\mathrm{v}} 1.2,297 \mathrm{bp}\right), S C N 3 A$ $\left(\mathrm{Na}_{\mathrm{v}} 1.3,367\right.$ bp), SCN4A $\left(\mathrm{Na}_{\mathrm{v}} 1.4,317 \mathrm{bp}\right), S C N 5 A$ $\left(\mathrm{Na}_{\mathrm{v}} 1.5,294 \mathrm{bp}\right), S C N 8 A\left(\mathrm{Na}_{\mathrm{v}} 1.6,207 \mathrm{bp}\right), S C N 9 A$ $\left(\mathrm{Na}_{\mathrm{v}} 1.7,289 \mathrm{bp}\right), S C N 10 A\left(\mathrm{Na}_{\mathrm{v}} 1.8,347 \mathrm{bp}\right), S C N 11 A$ $\left(\mathrm{Na}_{\mathrm{v}} 1.9,272 \mathrm{bp}\right)$ and the related isoform SCN7A $\left(\mathrm{Na}_{\mathrm{x}^{\prime}}\right.$ 327 bp) were all expressed in human sperm cDNA (Fig 1). Splice variants of $\mathrm{Na}_{\mathrm{v}} 1.7$ and $\mathrm{Na}_{\mathrm{v}} 1.8$, that resulted from the deletion of exon 5 and 8 , respectively, were also observed (Fig. 1). In the case of $\mathrm{Na}_{\mathrm{v}} 1.7$, both the wild type and the splice variant were detected in some sperm samples while only the splice variant was present in other sperm cDNAs (see Fig. 1) The mRNAs of the $\mathrm{Na}_{\mathrm{v}} \beta$ subunits $S C N 1 B\left(\beta_{1}, 236 \mathrm{bp}\right), S C N 3 B\left(\beta_{3}, 346 \mathrm{bp}\right)$, and $S C N 4 B$ $\left(\beta_{4}, 217 \mathrm{bp}\right)$, and of the reference gene $A C T B$ (362 bp) were also detected (Fig. 1, not shown for ACTB). All PCR products expressed in sperm cDNA were present in human testis cDNA (Fig. 1).

No PCR products were detected in the three negative controls showing the absence of genomic DNA contamination and that reagents were free of target sequence contamination. Fig. 1 shows the negative control with no RNA in the reverse transcriptase reaction.

\section{Immunodetection of voltage-gated $\mathrm{Na}^{+}$channel proteins in human sperm}

Immunofluorescence analysis demonstrated that most $\mathrm{Na}_{\mathrm{v}} \alpha$ subunits were present in the plasma membrane of human spermatozoa, and showed specific and different sites of localization (Fig. 2). SCN2A $\left(\mathrm{Na}_{\mathrm{v}} 1.2\right)$ immunos- taining was located in the flagellum and over the postequatorial region of the head. SCN4A $\left(\mathrm{Na}_{\mathrm{v}} 1.4\right)$ was present over the head and the flagellum midpiece, and the most intense immunofluorescence was detected in the post-acrosomal region around the connecting piece. SCN5A $\left(\mathrm{Na}_{\mathrm{v}} 1.5\right)$ staining was strictly localized in the postequatorial region of the head. SCN8A $\left(\mathrm{Na}_{\mathrm{v}} 1.6\right)$ was present in the flagellum principal piece with a faint fluorescence staining being observed around the neck. SCN9A $\left(\mathrm{Na}_{\mathrm{v}} 1.7\right)$ was mainly found around the connecting piece with a less intense immunostaining of the sperm head and flagellum. A strong positive signal for SCN10A $\left(\mathrm{Na}_{\mathrm{v}} 1.8\right)$ was observed along the tail and around the connecting piece, with a less intense signal detected in the sperm head, mostly in the post-equatorial region. SCN11A $\left(\mathrm{Na}_{\mathrm{v}} 1.9\right)$ was present over the acrosomal region of the head and in the flagellum midpiece. The atypical isoform SCN7A $\left(\mathrm{Na}_{\mathrm{x}}\right)$ was present in the flagellum and in the equatorial segment of the head (Fig. 2). The antibodies for SCN1A $\left(\mathrm{Na}_{\mathrm{v}} 1.1\right)$ and SCN3A $\left(\mathrm{Na}_{\mathrm{v}} 1.3\right)$ did not give any positive signal (not shown).

Experiments were repeated at least three times with identical localization sites for each $\mathrm{Na}_{\mathrm{v}}$ channel in all cases. Immunogenic peptides were only available for $\mathrm{Na}_{\mathrm{v}} 1.1$, $\mathrm{Na}_{\mathrm{v}} 1.3$ and $\mathrm{Na}_{\mathrm{v}}$ 1.6. Therefore, we could only assay the $\mathrm{Na}_{\mathrm{v}} 1.6$ one. Preincubation of the $\mathrm{Na}_{\mathrm{v}} 1.6$ primary antiserum (1:500 dilution) with the immunogenic peptide (5 $\mu \mathrm{g} / \mathrm{ml}$ ) caused an almost complete disappearance of the fluorescent signal (see Fig. 3). In addition, and for all $\mathrm{Na}_{\mathrm{v}}$ proteins assayed, unspecific binding was not observed in the two negative controls that were not exposed to the primary antibodies.
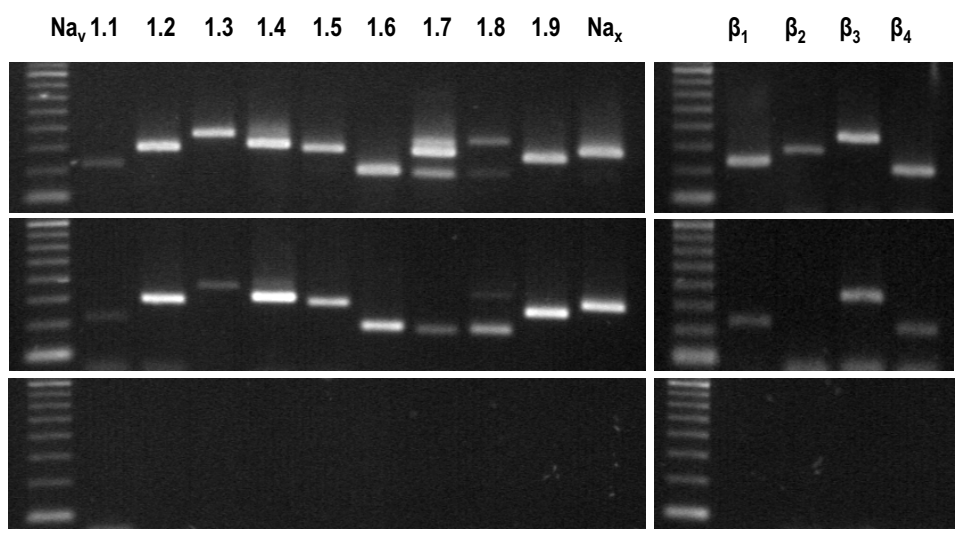

TESTIS

SPERM

(-) CONTROL

\section{Figure I}

Voltage-gated $\mathrm{Na}^{+}$channel gene expression in human sperm. Agarose gel showing expression of messenger RNA for voltage-gated $\mathrm{Na}^{+}$channel $\alpha$ and $\beta$ subunits and $\mathrm{Na}_{x}$ in human testis and sperm. The specific bands were not detected in the negative controls and the one with no added RNA in the reverse transcriptase reaction is shown. M, molecular weight standards. 

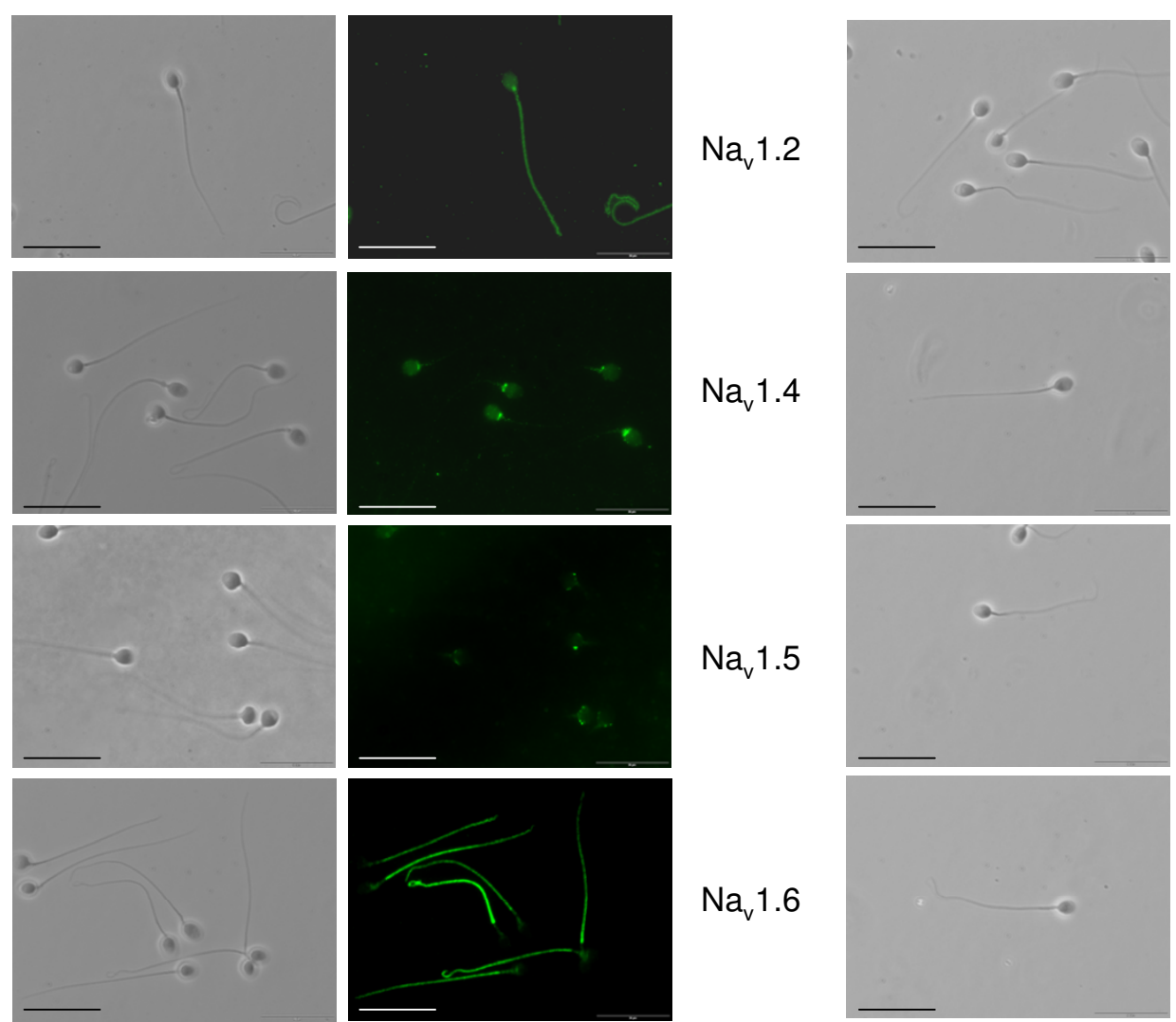

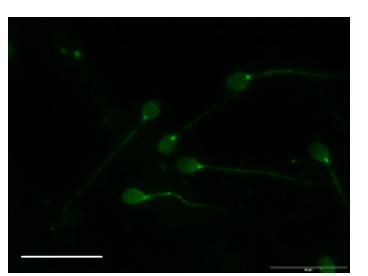

$\mathrm{Na}_{\mathrm{v}} 1.7$

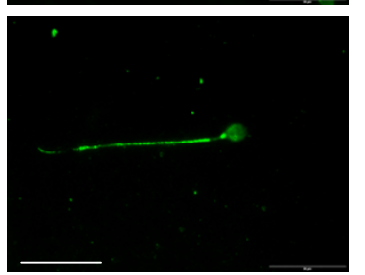

$\mathrm{Na}_{\mathrm{v}} 1.8$

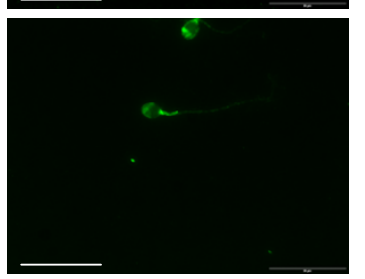

$\mathrm{Na}_{\mathrm{v}} 1.9$

$\mathrm{Na}_{\mathrm{v}} 1.6$
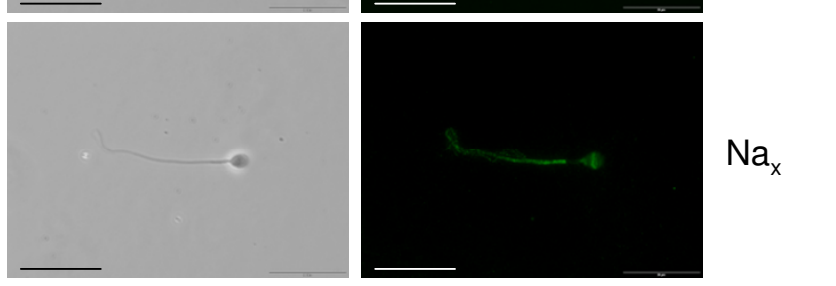

\section{Figure 2}

Immunofluorescent localization of voltage-gated $\mathrm{Na}^{+}$channels in human sperm. Immunofluorescence and corresponding phase-contrast images of sperm cells stained with primary antibodies against $\mathrm{Na}_{\mathrm{v}} \mathrm{l}$. I-I.9 and $\mathrm{Na}_{\mathrm{x}}$ showing specific localizations for each $\mathrm{Na}^{+}$channel. Experiments were performed at least six times for each channel with similar results. Scale bar: $20 \mu \mathrm{M}$.

\section{Effects of the voltage-gated $\mathrm{Na}^{+}$channel agonist veratridine on human sperm motility}

Veratridine $\left(10^{-8} \mathrm{M}-3 \times 10^{-5} \mathrm{M}\right)$ caused time- and concentration-dependent increases in progressive motility $(\mathrm{A}+\mathrm{B}$ grade) in capacitated sperm cells. The percentage of sperm $\mathrm{A}+\mathrm{B}$ grades measured $5 \mathrm{~min}$ before (initial value) and 30 min after treatment with vehicle (paired controls) or veratridine, respectively, were: $62.7 \pm 5.0,61.5 \pm 5.4$ and 78.9 \pm 3.1 for veratridine $10^{-6} \mathrm{M}(n=12, P<0.05$, veratridine $v$ initial value and solvent-treated control), and $59.8 \pm$ $5.6,57.7 \pm 7.2$ and $82.3 \pm 4.4$ for veratridine $10^{-5} \mathrm{M}(n=$ $8, P<0.05$, veratridine $v s$ initial value and solvent-treated control). Compared with vehicle-treated cells, the effects were significant at concentrations $>3 \times 10^{-7} \mathrm{M}$ and were observed for at least $1 \mathrm{~h}$ of incubation (Fig. 4A, 4B).

The veratridine-induced rise in progressive motility increased slowly during the observation period (60 min) and was initially due mainly to an increase in the percentage of B grade cells (Fig. 4B). During the incubation time, this was replaced gradually by an increase in the percentage of A motility grade spermatozoa (Fig. 4B). The increase in progressive motility $(\mathrm{A}+\mathrm{B}$ grade cells) was accompanied by a concomitant decrease in both $\mathrm{C}$ and $\mathrm{D}$ grade cells (Fig. 4).

\section{Effects of veratridine on intracellular free $\mathrm{Ca}^{2+}$ concentration, $\left[\mathrm{Ca}^{2+}\right]_{i}$}

Veratridine $\left(10^{-6} \mathrm{M}\right)$ did not modify $\left[\mathrm{Ca}^{2+}\right]_{\mathrm{i}}$ in Fura-2loaded human sperm cells (Fig. 5). No effects were observed even after prolonged periods of incubation (30 min, not shown). Subsequent addition of progesterone $\left(10^{-6} \mathrm{M}\right)$ to the same sperm aliquot caused a biphasic $\left[\mathrm{Ca}^{2+}\right]_{\mathrm{i}}$ response consisting in a rapid transient peak followed by a decay to $\left[\mathrm{Ca}^{2+}\right]_{\mathrm{i}}$ levels slightly over basal ones and a lower sustained plateau phase which persisted during the time of stimulation with progesterone (Fig. 5).

\section{Discussion}

This study shows for the first time that voltage-dependent $\mathrm{Na}^{+}$channels are present, and at least some of them are functionally active, in human sperm cells. Ion channels play a central role in the regulation of sperm intra- and inter-cellular signaling [13-15,28-31]. The rapid ion fluxes 

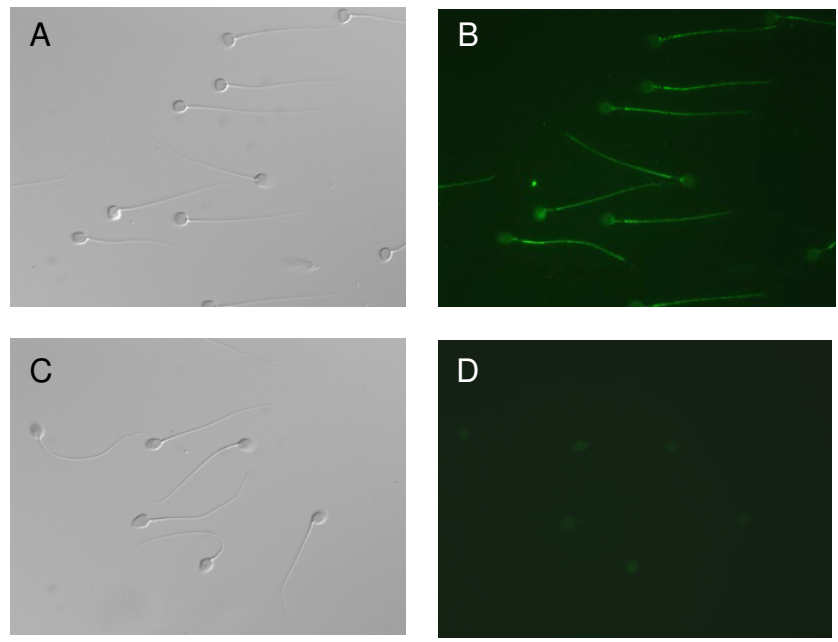

Figure 3

Specificity of the $\mathrm{Na}_{\mathrm{v}} \mathbf{I} .6$ primary antibody. Immunofluorescence $(B, D)$ and corresponding phase-contrast image $(A, C)$ of sperm cells stained with primary antibodies against $\mathrm{Na}_{\mathrm{v}} \mathrm{I} .6$ (I:500 dilution) in the absence (B) and presence (D) of immunogenic peptide $(5 \mu \mathrm{g} / \mathrm{ml})$.

through these membrane proteins permit a quick transfer of information between sperm and its surrounding $[14,15]$. This communication is essential for correct sperm guidance throughout the female reproductive tract as well as for acquisition of fertilization competence and interaction with the oocyte [12-17]. Many different ion channels have been identified in the sperm cell membrane. Among them, $\mathrm{Ca}^{2+}, \mathrm{K}^{+}$and anion channels are widely distributed in the head and flagellum and play an important role in regulating sperm function including motility, capacitation and acrosome reaction [13,14,17,28-31]. $\mathrm{Na}^{+}$channels should also be abundantly expressed in sperm, as the gradient of this ion across the plasma membrane plays a central role in the regulation of $\mathrm{E}_{\mathrm{m}^{\prime}}$ a parameter that govern the rates and direction of ion-flow through channels and exchangers and modulates $\mathrm{pH}_{\mathrm{i}}[11,14,19]$. It is well known that the process of capacitation is accompanied by important changes in sperm plasma membrane potential with a turn to a hyperpolarized state accompanied by an increase in $\mathrm{pH}_{\mathrm{i}}[13,14]$. This hyperpolarization seems to be related with an increase in $\mathrm{K}^{+}$permeability and a decrease in $\mathrm{Na}^{+}$permeability $[14,19,20]$. In this context, the presence of epithelial $\mathrm{Na}^{+}$channels of the $\mathrm{ENaC}$ family has been demonstrated in sperm cells [19].

No studies have been made to identify the presence of voltage-dependent $\mathrm{Na}^{+}$channels in spermatozoa. This is probably due to the classical belief that these channels were present almost exclusively in nerves, skeletal muscle, and heart. As a consequence, little is known about the function of $\mathrm{Na}_{\mathrm{v}}$ channels in other tissues and cells, and
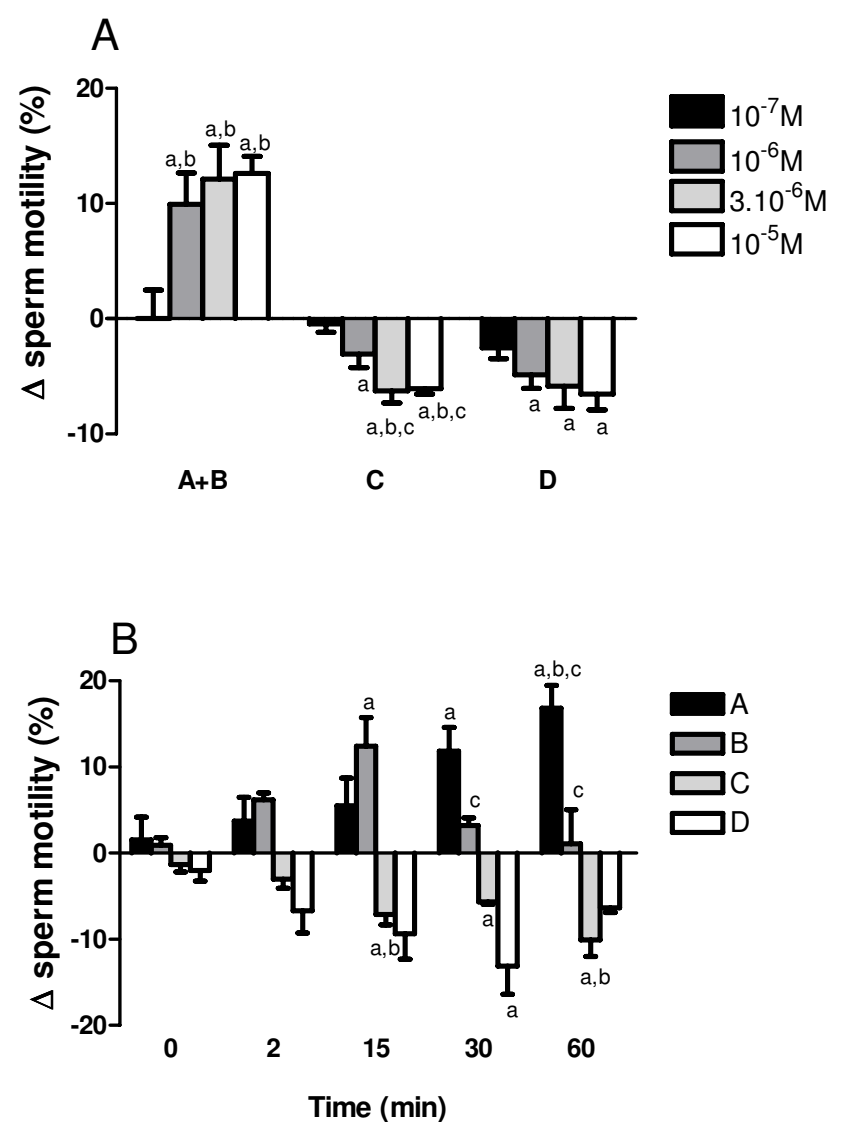

Figure 4

Effects of veratridine on human sperm motility. (A) Dose-response effects of veratridine $\left(10^{-7} \mathrm{M}-10^{-5} \mathrm{M}\right)$ after 15 min incubation. Data represent percentage changes in sperm $A+B, C$ and $D$ motility grades between samples treated with veratridine and its solvent (paired controls). ${ }^{a} P<0.05$ versus responses in solvent-treated controls. bP $<0.05$ versus responses to veratridine $10^{-7} \mathrm{M}$; $c P<0.05$ versus responses to veratridine $10^{-6} \mathrm{M}$, one-way ANOVA. (B) Timecourse of the effects of veratridine $\left(3 \times 10^{-6} \mathrm{M}\right)$ after 2,15 , 30 and $60 \mathrm{~min}$ incubation. Data represent percentage changes in sperm $A, B, C$ and $D$ motility grades between samples treated with veratridine and its solvent (paired controls). a $P<0.05$ versus responses at time 0 ; $P P<0.05$ versus responses at time $2, c P<0.05$ versus responses at time 15 , one-way ANOVA. Each bar is the mean with SEM of 6-12 different experiments.

particularly, at the reproductive level $[9,27]$. The present findings shows that the mRNAs encoding all known $\mathrm{Na}_{\mathrm{v}} \alpha$ subunits and three $\beta$ subunits are expressed in sperm cells. As sperm cells appear to be transcriptionally inactive, the mRNAs isolated from these cells would reflect gene expression processes that have taken place during earlier stages of spermatogenesis and, in good agreement, our results show that all VGSC mRNAs expressed in sperm were present in the human testis. The function of sperm 


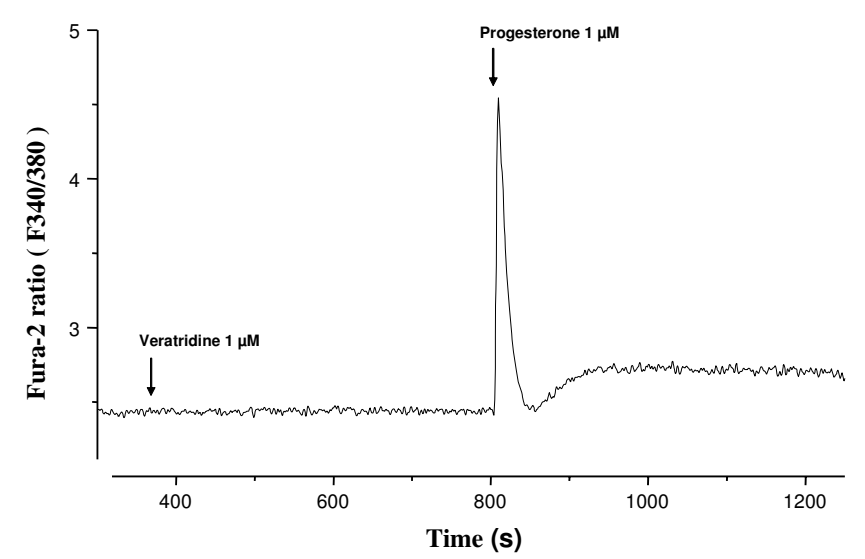

Figure 5

Effects of veratridine $\left(10^{-6} \mathrm{M}\right)$ and progesterone $\left(10^{-6}\right.$ M) on intracellular free $\mathrm{Ca}^{2+}$ levels, $\left[\mathrm{Ca}^{2+}\right]_{\mathrm{i}}$, in human sperm cells loaded with Fura-2. The trace is representative of typical results obtained in 10 different experiments. The $X$ Axis shows time in seconds with respect to addition of veratridine and progesterone and the $Y$ axis shows $\left[\mathrm{Ca}^{2+}\right]_{i}$ data expressed by the ratio of F340/F380 signals.

mRNAs remains poorly understood [16,32,33]. A recent report has shown the existence of changes in the expression of several sperm proteins in the presence of a specific inhibitor of mitochondrial translation [34] indicating that, at least part of the mRNAs could be translated into proteins in sperm mitochondria [35] and play a role in the regulation of sperm physiology. Other sperm mRNAs could be transferred to the oocyte and be necessary for fertilization and/or for the initial steps of embryo development $[32,33]$.

Immunofluorescence studies demonstrate that, with the exception of $\mathrm{Na}_{\mathrm{v}} 1.1$ and $\mathrm{Na}_{\mathrm{v}} 1.3$, all VGSC proteins could be detected in mature sperm. Moreover, the distribution of each $\mathrm{Na}_{\mathrm{v}}$ channel was very homogeneous within and throughout samples, with only minor changes in staining intensity. This wide expression and the specific and distinct distribution pattern of each $\mathrm{Na}_{\mathrm{v}}$ channel argue for an important role of VGSC in the regulation of sperm function. Some of them (i.e., $\mathrm{Na}_{\mathrm{v}} 1.2, \mathrm{Na}_{\mathrm{v}} 1.4$ and $\mathrm{Na}_{\mathrm{v}} 1.7$ ) were mainly found in the connecting piece, a region which play an important role in sperm signaling $[17,36]$. Of particular interest was the observation that $\mathrm{Na}_{\mathrm{v}} 1.8 \mathrm{mRNA}$ and protein are expressed in mature spermatozoa. Previous studies have suggested that this TTX-resistant channel is selectively expressed in a particular population of C-fiber and $A \delta$-fiber-associated sensory neurons and plays a key role in sensory transmission and pain perception $[2,3,9]$. The present data clearly shows that $\mathrm{Na}_{\mathrm{v}} 1.8$ is also expressed in cells of non-neuronal origin suggesting that, besides its role in nociception, $\mathrm{Na}_{\mathrm{v}} 1.8$ plays additional, still undefined roles in male reproduction. The localization of $\mathrm{Na}_{\mathrm{v}} 1.8$ in the flagellum and around the neck led us to hypothesize that it could be involved in modulation of flagellar activity and sperm motility.

In an attempt to investigate further the functional role of $\mathrm{Na}_{\mathrm{v}}$ channels in mature spermatozoa we analyzed the effect of the $\mathrm{Na}_{\mathrm{v}}$ activator veratridine on sperm motility. Veratridine caused time- and concentration-dependent increases in progressive motility. The effects of veratridine were characterized by an initial increase in $\mathrm{B}$ grade cells followed, after 15-30 min incubation, by a predominant increase in rapidly progressive A grade cells. This was accompanied by a decrease in sperm immotility with a reduction of $\mathrm{C}$ and $\mathrm{D}$ grade sperm cells. Veratridine acts by inhibiting $\mathrm{Na}_{\mathrm{v}}$ inactivation after spontaneous channel opening and, therefore, it is likely that effects could develop slowly, as channels spontaneously open and then become modified by veratridine. This mechanism of action could explain the gradual change in motility observed during the incubation time. Taken together, these data demonstrate that VGSCs participate in the regulation of human sperm motility.

The veratridine-induced increases in sperm progressive motility were not accompanied by any change in $\left[\mathrm{Ca}^{2+}\right]_{i}$. In the same sperm samples, progesterone increased $\left[\mathrm{Ca}^{2+}\right]_{\mathrm{i}}$ and caused the typical biphasic $\left[\mathrm{Ca}^{2+}\right]_{\mathrm{i}}$ response, in accordance with previous reports $[15,17,25,28]$. The opening of $\mathrm{Na}_{\mathrm{v}}$ channels should produce a membrane depolarization with the subsequent opening of $\mathrm{Ca}^{2+}$ channels or may cause an influx of $\mathrm{Ca}^{2+}$ through the $\mathrm{Na}^{+} / \mathrm{Ca}^{2+}$ exchanger acting in the reverse mode. Thus, the reasons why veratridine failed to modify $\left[\mathrm{Ca}^{2+}\right]_{\mathrm{i}}$ remain unclear. A possible explanation is that veratridine-sensitive VGSCs may be mostly located in a particular tail segment $[15,37]$ thus producing a low $\left[\mathrm{Ca}^{2+}\right]_{\mathrm{i}}$ signal that could not be detected by fluorimetry or, alternatively, that opening of sperm VGSCs activate additional mechanisms that oppose $\mathrm{Ca}^{2+}$ influx. In any case, our data strongly suggest that sperm motility could proceed in a $\mathrm{Na}^{+}$-dependent manner. The participation of a variety of $\mathrm{Ca}^{2+}$-dependent and $\mathrm{Na}^{+}$-dependent processes will ensure motility in a cell for which movement is essential to achieve its physiological function. This could explain the redundant expression of $\mathrm{Na}_{\mathrm{v}}$ and many other ion channels in sperm cells, as redundancy is not only a way to acquire new functions but also, and more important for a cell, for function conservation [38]. The use of $\mathrm{Na}^{+}$and $\mathrm{Ca}^{2+}$ sources has additional advantages for the sperm cell since movement based on $\mathrm{Na}^{+}$currents should provide a more economic energy source than movement based exclusively on $\mathrm{Ca}^{2+}$ currents [27]. Energy saving should be essential for a transcriptionally inactive small cell which must transverse the whole uterus and enter the oviduct to find its target cell, the 
oocyte. Finally, it is possible that the participation of $\mathrm{Na}^{+}-$ and $\mathrm{Ca}^{2+}$-dependent mechanisms could vary during the sperm travel throughout the female reproductive tract depending on the degree of sperm activation and membrane potential state. In fact, sperm motility should be finely regulated to asseverate a good progressive motility while avoiding the development of hyperactivated motility that would led to a premature activation in an inappropriate place $[12,17,22,36]$. In this context, it is tempting to speculate that $\mathrm{Na}_{\mathrm{v}}$ channels could play a more important role in the non-capacitated and in the initial capacitation steps and be inactivated during capacitation, when sperm membrane hyperpolarizes previously to the acrosome reaction.

\section{Conclusion}

This research shows the presence of voltage-dependent $\mathrm{Na}^{+}$channels in human sperm and supports a role for these channels in the regulation of mature sperm function. The data increase the diversity of ion channels expressed in spermatozoa and confirm the importance and complexity of sperm function regulation by ion channels.

\section{Abbreviations}

VGSC: voltage-gated sodium channel; $\left[\mathrm{Ca}^{2+}\right]_{\mathrm{i}}$ : intracellular free $\mathrm{Ca}^{2+}$ levels; TTX: tetrodotoxin; $\mathrm{pH}_{\mathrm{i}}$ : intracellular $\mathrm{pH} ; \mathrm{E}_{\mathrm{m}}$ : plasma membrane potential; ENaC: epithelial sodium channel; BSA: bovine serum albumin; WHO: World Health Organization; mHTF: modified human tubal fluid; PBS: phosphate-buffered saline; ANOVA: analysis of variance.

\section{Competing interests}

The authors declare that they have no competing interests.

\section{Authors' contributions}

FMP carried out PCR and immunofluorescence experiments, participated in the design of the study and helped to write the manuscript. CGR and MFS participated in sample collection, capacitation and analysis of sperm parameters. MGC and ACR carried out motility studies and fluorimetric measurements. MLC wrote the manuscript and participated in the design of the study. All authors read and approved the final manuscript.

\section{Acknowledgements}

This work was supported by grants from Junta de Andalucía (P08-CVI04I85) and Ministerio de Educación y Ciencia (CTQ2007-6I024/BQU), Spain.

\section{References}

I. Tamargo J, Delpón E, Pérez O, Valenzuela C: Antiarrhythmic actions of drugs interacting with sodium channels. In lon Channel Pharmacology Edited by: Soria B, Cena V. Oxford: Oxford University Press; 1998:74-94.
2. Catterall WA, Goldin AL, Waxman SG: International Union of Pharmacology. XXXIX. Compendium of voltage-gated ion channels: sodium channels. Pharmacol Rev 2003, 55:575-578.

3. Wood JN, Boorman JP, Okuse K, Baker MD: Voltage-gated sodium channels and pain pathways. J Neurobiol 2004, 6 I:55-7I.

4. Yu FH, Catterall WA: Overview of the voltage-gated sodium channel family. Genome Biol 2003, 4:207.I-207.7.

5. Plummer NW, Meisler MH: Evolution and diversity of mammalian sodium channel genes. Genomics 1999, 57:323-331.

6. George AL Jr, Knittle TJ, Tamkun MM: Molecular cloning of an atypical voltage-gated sodium channel expressed in human heart and uterus: evidence for a distinct gene family. Proc Natl Acad Sci USA 1992, 89:4893-4897.

7. Felipe A, Knittle TJ, Doyle KL, Tamkun MM: Primary structure and differential expression during development and pregnancy of a novel voltage-gated sodium channel in the mouse. J Biol Chem 1994, 269:30125-30131.

8. Brackenbury WJ, Isom LL: Voltage-gated $\mathrm{Na}^{+}$channels: potential for beta subunits as therapeutic targets. Expert Opin Ther Targets 2008, I2:1191-1203.

9. Candenas L, Seda M, Noheda P, Buschmann H, Cintado CG, Martin JD, Pinto FM: Molecular diversity of voltage-gated sodium channel alpha and beta subunit mRNAs in human tissues. Eur J Pharmacol 2006, 541:9-16.

10. David M, Martínez-Mármol R, Gonzalez T, Felipe A, Valenzuela C: Differential regulation of $\mathrm{Na}(\mathrm{v})$ beta subunits during myogenesis. Biochem Biophys Res Commun 2008, 368:76I-766.

11. Garcia MA, Meizel S: Regulation of intracellular pH in capacitated human spermatozoa by a $\mathbf{N a}+/ \mathbf{H}+$ exchanger. $\mathrm{Mol}$ Reprod Dev 1999, 52:189-195.

12. Flesch FM, Gadella BM: Dynamics of the mammalian sperm plasma membrane in the process of fertilization. Biochim Biophys Acta 2000, 1469:197-235.

13. Visconti PE, Westbrook VA, Chertihin O, Demarco I, Sleight S, Diekman $A B$ : Novel signaling pathways involved in sperm acquisition of fertilizing capacity. J Reprod Immunol 2002, 53:I33-I50.

14. Darszon A, Acevedo Jj, Galindo BE, Hernández-González EO, Nishigaki T, Treviño CL, Wood C, Beltrán C: Sperm channel diversity and functional multiplicity. Reproduction 2006, I 31 :977-988.

15. Jiménez-González MC, Gu Y, Kirkman-Brown J, Barratt CL, Publicover S: Patch-clamp 'mapping' of ion channel activity in human sperm reveals regionalisation and co-localisation into mixed clusters. J Cell Physiol 2007, 2 13:80 I-808.

16. Garrido N, Remohí J, Martínez-Conejero JA, García-Herrero S, Pellicer A, Meseguer M: Contribution of sperm molecular features to embryo quality and assisted reproduction success. Reprod Biomed Online 2008, 17:855-865.

17. Publicover SJ, Giojalas LC, Teves ME, de Oliveira GS, Garcia AA, Barratt $\mathrm{CL}$, Harper $\mathrm{CV}$ : $\mathrm{Ca}^{2+}$ signalling in the control of motility and guidance in mammalian sperm. Front Biosci 2008, 13:5623-5637.

18. Flesch FM, Brouwers JF, Nievelstein PF, Verkleij AJ, van Golde LM, Colenbrander B, Gadella BM: Bicarbonate stimulated phospholipid scrambling induces cholesterol redistribution and enables cholesterol depletion in the sperm plasma membrane. J Cell Sci 200I, I I 4:3543-3555.

19. Hernández-González EO, Sosnik J, Edwards J, Acevedo JJ, MendozaLujambio I, López-González I, Demarco I, Wertheimer E, Darszon A, Visconti PE: Sodium and epithelial sodium channels participate in the regulation of the capacitation-associated hyperpolarization in mouse sperm. J Biol Chem 2006, 28 I:5623-5633.

20. Acevedo JJ, Mendoza-Lujambio I, de la Vega-Beltran JL, Trevino CL, Felix R, Darszon A: $K_{A T P}$ channels in mouse spermatogenic cells and sperm, and their role in capacitation. Dev Biol 2006, 289:395-405.

21. Ravina CG, Seda M, Pinto FM, Orea A, Fernandez-Sanchez M, Pintado $\mathrm{CO}$, Candenas ML: $\mathbf{A}$ role for tachykinins in the regulation of human sperm motility. Hum Reprod 2007, 22:1617-1625.

22. Agirregoitia E, Carracedo A, Subirán N, Valdivia A, Agirregoitia N, Peralta L, Velasco G, Irazusta J: The CB(2) cannabinoid receptor regulates human sperm cell motility. Fertil Steril 2009 in press.

23. World Health Organization: WHO laboratory Manual for the examination of human semen and sperm-cervical mucus interaction 4th edition. Cambridge: Cambridge University Press; 1999.

24. Agirregoitia E, Valdivia A, Carracedo A, Casis L, Gil J, Subiran N, Ochoa C, Irazusta J: Expression and localization of delta-, 
kappa-, and mu-opioid receptors in human spermatozoa and implications for sperm motility. J Clin Endocrinol Metab 2006, 91:4969-4975.

25. Espino J, Mediero M, Lozano GM, Bejarano I, Ortiz A, García JF, Pariente JA, Rodríguez $A B$ : Reduced levels of intracellular calcium releasing in spermatozoa from asthenozoospermic patients. Reprod Biol Endocrinol 2009, 7:II.

26. Guibert C, Marthan R, Savineau JP: 5-HT induces an arachidonic acid-sensitive calcium influx in rat small intrapulmonary artery. Am J Physiol Lung Cell Mol Physiol 2004, 286:LI228-LI 236.

27. Seda M, Pinto FM, Wray S, Cintado CG, Noheda P, Buschmann H, Candenas ML: Functional and molecular characterization of voltage-gated sodium channels in uteri from nonpregnant rats. Biol Reprod 2007, 77:855-863.

28. Conner SJ, Lefièvre L, Kirkman-Brown J, Michelangeli F, JimenezGonzalez C, Machado-Oliveira GS, Pixton KL, Brewis IA, Barratt CL, Publicover SJ: Understanding the physiology of pre-fertilisation events in the human spermatozoa-a necessary prerequisite to developing rational therapy. Soc Reprod Fertil Suppl 2007, 63:237-255.

29. Qi H, Moran MM, Navarro B, Chong JA, Krapivinsky G, Krapivinsky L, Kirichok Y, Ramsey IS, Quill TA, Clapham DE: All four CatSper ion channel proteins are required for male fertility and sperm cell hyperactivated motility. Proc Natl Acad Sci USA 2007, 104:1219-1223.

30. Xu WM, Shi QX, Chen WY, Zhou CX, Ni Y, Rowlands DK, Yi Liu G, Zhu H, Ma ZG, Wang XF, Chen ZH, Zhou SC, Dong HS, Zhang XH, Chung YW, Yuan YY, Yang WX, Chan HC: Cystic fibrosis transmembrane conductance regulator is vital to sperm fertilizing capacity and male fertility. Proc Natl Acad Sci USA 2007, 104:9816-9821.

31. Liu B, Wang Z, Zhang W, Wang X: Voltage-dependent anion channels (VDAC) in human spermatozoa. Biochem Biophys Res Commun 2009, 378:366-370.

32. Ostermeier GC, Dix DJ, Miller D, Khatri P, Krawetz SA: Spermatozoal RNA profiles of normal fertile men. Lancet 2002, 360:772-777.

33. Miller D, Ostermeier GC, Krawetz SA: The controversy, potential and roles of spermatozoal RNA. Trends Mol Med 2005, II:I56-163.

34. Zhao C, Guo XJ, Shi ZH, Wang FQ, Huang XY, Huo R, Zhu H, Wang $X R$, Liu JY, Zhou ZM, Sha JH: Role of translation by mitochondrial-type ribosomes during sperm capacitation: An analysis based on a proteomic approach. Proteomics 2009, 9:1385-1399.

35. Gur $\mathrm{Y}$, Breitbart $\mathrm{H}$ : Mammalian sperm translate nuclearencoded proteins by mitochondrial-type ribosomes. Genes Dev 2006, 20:4||-4I6.

36. Ho HC, Suarez SS: Characterization of the intracellular calcium store at the base of the sperm flagellum that regulates hyperactivated motility. Biol Reprod 2003, 68:1590-I596.

37. Suarez SS, Marquez B, Harris TP, Schimenti JC: Different regulatory systems operate in the midpiece and principal piece of the mammalian sperm flagellum. Soc Reprod Fertil Suppl 2007, 65:33I-334.

38. Pennefather JN, Lecci A, Candenas ML, Patak E, Pinto FM, Maggi CA: Tachykinins and tachykinin receptors: a growing family. Life Sci 2004, 74:|445-| 463.
Publish with Bio Med Central and every scientist can read your work free of charge

"BioMed Central will be the most significant development for disseminating the results of biomedical research in our lifetime. "

Sir Paul Nurse, Cancer Research UK

Your research papers will be:

- available free of charge to the entire biomedical community

- peer reviewed and published immediately upon acceptance

- cited in PubMed and archived on PubMed Central

- yours - you keep the copyright
BioMedcentral 